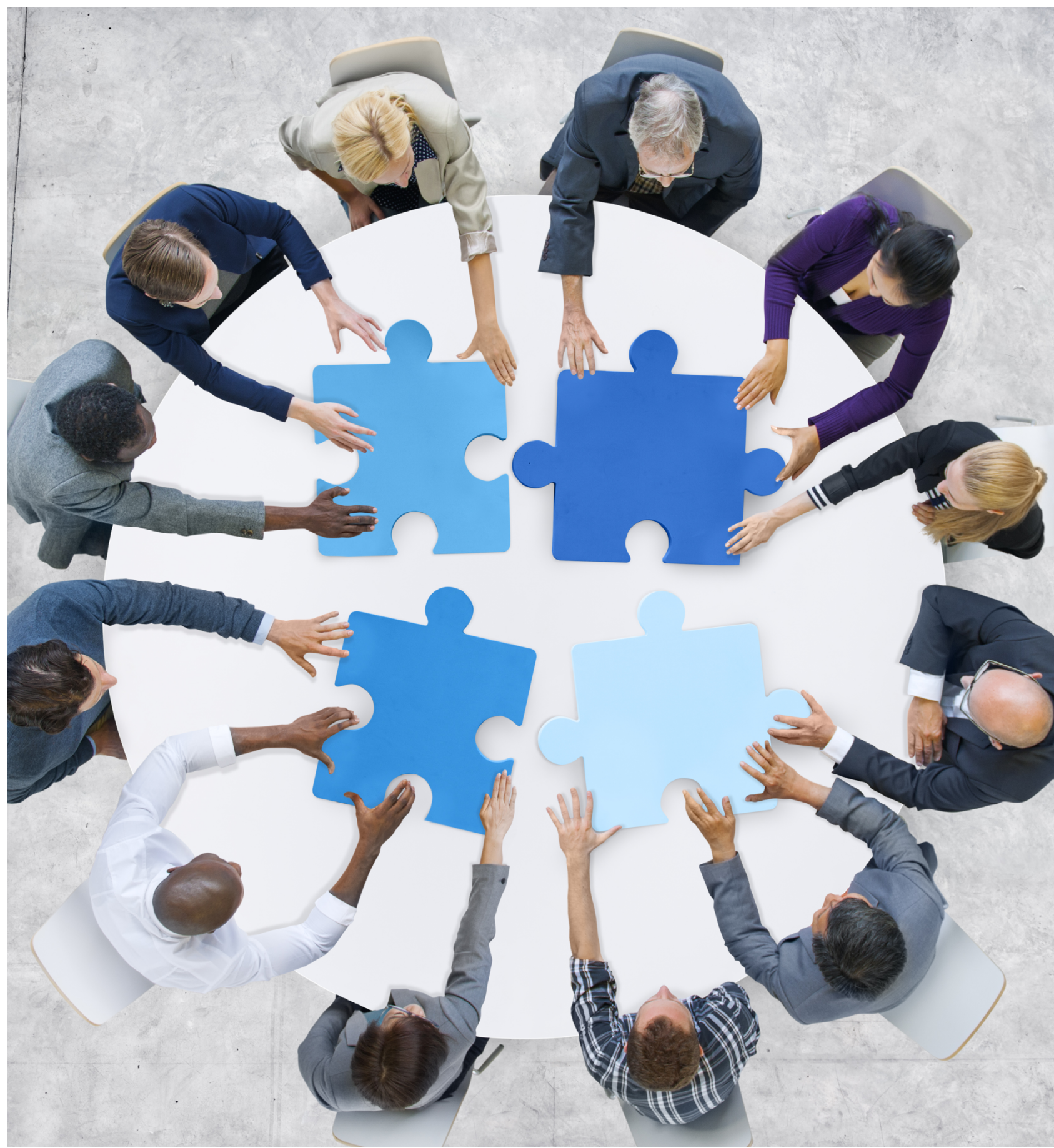

\title{
ACADEMIA E \\ PRÁTICA EM SIMBIOSE
}




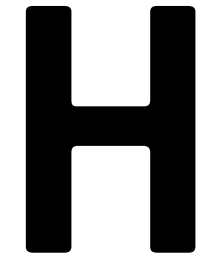

á algumas décadas, o conhecimento produzido nas ciências administrativas vem sendo questionado por falta de impacto na prática. Podemos dizer que há controvérsias sobre esse suposto afastamento, uma vez que professores de escolas de Administração realizam consultorias, participam de boards de empresas, ministram aulas em inúmeros programas de educação corporativa e MBAs. Nessas atividades, ficam em estreito contato com os praticantes, circulando conceitos (e modismos) produzidos na academia. Mas, ainda assim, esse questionamento persiste. Para aproximar ainda mais universidade e empresas, no mundo todo houve o crescimento de programas de Doutorado Profissional em Administração voltados exclusivamente para altos executivos. Conhecido como Doctorate in Business Administration (DBA), a modalidade tem várias escolas como expoentes, como Harvard, nos Estados Unidos, e Instituto de Empresas, na Espanha, para citar apenas dois exemplos. No Brasil, o programa foi aprovado recentemente pela Coordenação de Aperfeiçoamento de Pessoal de Nível Superior (CAPES).

Qual é a diferença entre o doutorado tradicional em Administração de Empresas e o Doutorado Profissional em Administração (DPA)? Seguem algumas características: o segundo programa não exige dedicação de tempo integral, é realizado em módulos que permitem a conciliação com as atividades executivas; está ancorado em conhecimento e teorias de última geração em Administração, com a diferença que o doutorando deve contribuir, na sua tese, com a prática administrativa de modo mais direto que o doutorado tradicional. Requer-se considerável prática executiva por parte dos candidatos, ao mesmo tempo que não há oferta de bolsas comumente presentes nos doutorados acadêmicos para dedicação integral.

O DPA oferece a possibilidade de altos executivos se aproximarem novamente da academia, convivendo com colegas de outras empresas e participando de debates conceituais mais substantivos, nem sempre possíveis no dia a dia corrido das empresas. Tal modalidade também permite que o praticante possa levar soluções inovadoras para seu campo de atuação. Muitos executivos queixam-se da superficialidade com que a vida nas empresas é gerida. O DPA permite o aprofundamento sistemático de questões cotidianas, com base em teorias e conceitos.
Essa edição especial da $G V$-executivo aborda essa temática e traz artigos de executivos que estão seguindo uma linha de pesquisa voltada à competitividade no programa de doutorado da Escola de Administração de Empresas da Fundação Getulio Vargas (FGV EAESP). Para começar, os professores Thomaz Wood Junior, Miguel Caldas e Renato Souza apontam para a necessidade de trazer mais perto a academia da prática (e vice-versa) com o texto Aproximando gregos e troianos. Eduardo Lopes dos Santos, executivo de recursos humanos, mostra saídas para o atual estado de esgotamento emocional de executivos, com o artigo A era do burnout. Alex Del Giglio, presidente da Agência de Fomento do Estado do Amazonas (AFEAM), trata de Os desafios do microcrédito no Amazonas. Marcio Lago Couto, pesquisador do Instituto Brasileiro de Economia (IBRE), propõe uma metodologia para evitar a aprovação de projetos de infraestrutura irrealistas no texto Para tapar o buraco da infraestrutura do Brasil. Por fim, Rafael Dan Schur, partner na consultoria $\mathrm{EY}$, discute como aprimorar a governança da informação para transformar inteligência analítica em valor no artigo A emergência da governança da informação.

Essa edição conta ainda com os artigos de Luis Vasconcellos, com um modelo para Gestão de desempenho na cadeia de suprimentos; Marcio Gabrielli e Frederico Turolla, Uma luz para as cidades, acerca de alternativas para melhorar a iluminação pública; e, em sintonia com o tema do Caderno Especial, Marisa Eboli, André Fischer, Fábio Moraes, Wilson Amorim e Luci Ferraz, discutem sobre as universidades acadêmicas e as universidades corporativas no artigo Concorrência ou convergência?

Completam esta edição a entrevista com Helisson Lemos, chief operating officer (COO - diretor de operações) da Movile, além das colunas Gestão, de Sarah Chaia, a respeito de compliance, um tema mais que relevante nos dias atuais; Fora da Caixa, de Samy Dana, abordando que os ricos tomam as piores decisões financeiras; Economia, de Paulo Sandroni, sobre a campanha eleitoral e o ajuste fiscal; e Sociedade e Gestão, de Vanessa Cepellos e João Lins, que tratam da tendência de envelhecimento da força de trabalho no país.

Boa leitura!

Maria José Tonelli - Editora chefe

Adriana Wilner - Editora adjunta 